\title{
The Conceptual Paradigms of the Psychological System of M. I. Demkov
}

\section{Концептуальні парадигми психологічної системи М. І. Демкова}

Mariia Dryhus

Ph.D. in Psychology, Senior

Researcher of the Chamata

Laboratory of Psychology

of Personality
Марія Дригус

кандидат психологічних наук, старший науковий співробітник

лабораторії психології

особистості імені П. Р. Чамати

E-mail: mariatrd33@gmail.com orcid.org/0000-0003-0648-0183

Researcher ID: G-4671-2018

\section{G.S. Kostiuk Institute of Iнститут психологї ілені} Psychology of NAPS of Ukraine, Г. С. Костюка НАПН України,

Kyiv, Ukraine

2, Pankivska street,

Kyiv, 01033 ли. Київ, Україна

вул. Паньківська, 2,

м. Київ, 01033

Original manuscript received March 04, 2019

Revised manuscript accepted March 29, 2019

\section{ABSTRACT}

The article presents the research on the conceptual paradigms of the psychological system proposed by M. I. Demkov. The psychological system proposed by M. I. Demkov in the context of conceptual paradigms of personal harmonious development and "spirit of learning" in the educational space are analysed theoretically and methodologically. The concept of personal harmonious development proposed by M. I. Demkov is reconstructed in the article. The scientist's conceptual vision of harmonious development and its architectonics is revealed. Harmonious development is understood as "strictly proportional 
formation of mind together with education of feelings and will». The article focuses on M. I. Demkov's vision of education as a factor for a child's harmonious development. The article states that M. I. Demkov, within child psychology, presented a voluminous palette of ontogenetic development; and within educational psychology, he organically revealed the essential characteristics of children's learning, as well as described formation of a personality during learning. Prevention of the harmonious development destruction and one-side personal development are also discussed.

The stylistic characteristics of a teacher's work in the system of "teacherpupil» interactions, aimed at development of facilitative interactions, are determined. The article emphasizes that M. I. Demkov defended the postulate of internal determination of educational activities.

The article also describes M. I. Demkov's vision of "the spirit of learning" as an organic unity of personal and social determination. The influence of the mega-system - society in general, - as well as the macro-system - school was revealed by him. According to M. I. Demkov, the core, dominant factor of "the spirit of learning" in a teacher's personality is unification of his / her high morality and his/her good education. M. I. Demkov introduced the concepts of "moral and educational element", "moral education» that characterize educational activities. The scientist outlined a reference image of a teacher. The article singles out the semantic, meaning-making quintessence of M. I. Demkov's approach to "the spirit of learning». The "spirit of learning" concept has been extrapolated onto the modern educational space.

Key words: education, harmonious development, determination, personality, psychological system, factors.

\section{Вступ}

Необхідність проведення ефективних трансформацій освітніх процесів передбачає знання вітчизняної наукової спадщини. Наприкінці XIX ст. у власне українській науковій думці складається самобутній, об'ємний і потужний за потенціалом прошарок психолого-педагогічного знання, який мав значний вплив на освітні процеси не лише на зламі XIX і XX ст., а й майже всієї першої чверті XX ст. Історична доля цих надбань була складною і несправедливою щодо них: спочатку вилучення як із наукового обігу, так і 3 педагогічної практики (Педагогічна енциклопедія, 1929), у результаті - їх повне забуття. Одним із визначних імен на 
тогочасному українському науковому небосхилі було ім'я вченого Михайла Івановича Демкова, який зробив неоціненний внесок у побудову теоретико-методологічного фундаменту освітнього процесу. Саме в українському науковому просторі у 90-х рр. XIX ст. ним здійснюється розробка таких кардинальних освітніх проблем, як принципи науки виховання, педагогічні правила й закони, педагогічні гіпотези й теорії; створення теорії «повноти розвитку сил і морального вдосконалення» ${ }^{1}$, системи виховання та особистісного розвитку дитини.

Працюючи над такою масштабною проблемою, як історія вітчизняної педагогіки, роботу над якою він розпочав у листопаді 1887 р. і яка, за його висловом, «іде повсякчас, якщо не враховувати коротких проміжків відпочинку й інших обов'язкових робіт для автора», вчений із кінця 1880-х - початку 1890-х рр. розпочинає розробку психологічних проблем освітнього простору. Впродовж десятиліття він презентує свої праці, що висвітлюють різні спектри дитячої та педагогічної психології, перша 3 яких - «Про самостійні заняття учнів (до питання про виховання волі)» (Демков, 1889). Аналіз наукової спадщини М. І. Демкова дає підстави стверджувати, що саме його науковий доробок є однією з підвалин фундаменту власне української дитячої та педагогічної психології (Дригус, 2004).

Зазначимо, що у вітчизняному науковому просторі освітня і наукова діяльність М. I. Демкова стає предметом вивчення педагогами-дослідниками лише у 90-х роках XX ст. Так, Н. I. Бєлкіна у дисертаційному дослідженні та низці наукових праць розкрила освітню діяльність і педагогічні погляди M. I. Демкова, а також висвітила його внесок у розробку історії вітчизняної педагогіки (Бєлкіна, 1998). Дослідниця Т. О. Самоплавська здійснила аналіз наукової спадщини М. I. Демкова як учителя, педагога, організатора освіти, історика педагогіки та методиста (Само-

\section{${ }^{1}$ Подаємо у визначенні автора.}


плавська, 2005). Психологічний аналіз творчої спадщини M. I. Демкова розпочинається нами на межі XX-XXI ст. В історіогенезі взірцем дослідження вітчизняної спадщини є аналіз психологічної спадщини К. Д. Ушинського, виконаний Г. С. Костюком і колективом співробітників Науково-дослідного інституту психології під його керівництвом (Костюк, 1963). Прикметно, що перша чверть XXI ст. відзначається розвідками історіогенези вітчизняних надбань персонологічного вектора у філософському, педагогічному та психологічному науковому просторі. Це, зокрема, знайшло репрезентацію у виданні «Українська педагогіка в персоналіях (у двох книгах) за редакцією О. В. Сухомлинської (Сухомлинська, Дічек, Самоплавська та ін., 2005); у бібліографічному словнику «Філософська думка в Україні» (Горський, Ткачук, Нічик й ін., 2002); у монографічному дослідженні В. В. Рибалки висвітлені теорії особистості у вітчизняній філософії, психології та педагогіці (Рибалка, 2015). У монографії Ю. Т. Рождественського «Психологія в Україні XVII - початку XIX ст. (спроба реконструкції та систематизації академічної спадщини)» розкрито формування основ психології в освітньому просторі України у творчому доробку сузір'я вітчизняних мислителів, зокрема, Феофана Прокоповича, Стефана Калиновського, Георгія Кониського (Рождественський, 2012). У колективній монографії «Становлення психологічної думки в Україні: провідні ідеї та історія розвитку» (Турбан, Сердюк, Рождественський та ін., 2014) висвітлено творчі здобутки фундатора сучасної вітчизняної психології Г. С. Костюка, вітчизняного психолога I. О. Сікорського. Серед зарубіжних дослідників психологічної спадщини виокремлюється концептуальний підхід норвезького професора Пера Саугстада (Saugstad, 2001, 2009, 2018), який, за оцінками, не має аналогів у сучасній психології. Прикметною рисою його творчого шляху в історії психології є репрезентація ученим дослідницького матеріалу в спектрах: «імена ідеї - біографії - напрямки - школи» . 
Нами уперше здійснена спроба реконструкції психологічної системи видатного українського вченого М. I. Демкова, щоб його ім'я та забуті творчі надбання включити в актуальний простір сучасної вітчизняної педагогічної та вікової психології.

Мета статті - здійснити теоретико-методологічний аналіз психологічної системи М. І. Демкова у контексті концептуальних парадигм гармонійного розвитку особистості та «духу навчання» в освітньому просторі.

\section{Завдання статті}

1. Здійснити аналіз концепції гармонійного розвитку особистості у психологічній системі М. І. Демкова.

2. Розкрити парадигмальну проблему «духу навчання» у контексті творчої спадщини М. I. Демкова.

\section{Методи та методики дослідження}

Підгрунтя наукового пошуку склали: методологія дослідження історіогенези наукової вітчизняної спадщини (Г. С. Костюк), генетико-моделюючий метод (С. Д. Максименко), теоретико-методологічний аналіз (порівняльний, аперцепційний), біографічний метод.

\section{Результати та дискусії}

У 90-х pp. XIX ст. у вітчизняному науковому простоpi видатним ученим М. I. Демковим була розроблена концепція гармонійного розвитку особистості (Демков, 1894а; 1894б; 1894в).

Слід зазначити, що вчений презентував своє бачення гармонійного розвитку в промові, виголошеній 11 червня 1894 р. на Акті Глухівського вчительського інституту. Значущість цієї промови для М. І. Демкова як педагога і вченого зумовлювалася тією обставиною, що він виголошував її для випускників, удостоєних звання міських учителів. У цій промові простежується архітектоніка бачення ним системи розвитку особистості; тут М. I. Демков скон- 
центрував усе те серцевинне, що вважав за потрібне донести молодій учительській зміні щодо проблеми виховання вчителем особистості дитини. Про непересічність промови вченого і високу її оцінку педагогічною громадськістю свідчить хоча б той факт, що вона була опублікована повністю у трьох виданнях «Педагогічного щотижневика» $(4,11,18$ червня 1894 р.) авторитетного на той час журналу «Гімназія» (Демков, 1894а; 1894б; 1894в). У зазначеній промові М. І. Демков окреслює синтезований абрис Учителя. В основі звання «вчитель», на його думку, - високі громадянські якості, зокрема любов до Батьківщини; метою діяльності вчителя є високоосяжний імператив - бути вірним слугою Вітчизни; змістом його праці є гармонійний розвиток підростаючої особистості на засадах високих ідеалів Істини, Добра і Краси.

Важливого громадянського, професійного й морального значення набуває його настанова: «Тому і тут, звертаючись із прощальним словом до наших колишніх вихованців, нині удостоєних звання ліських учителів, ми можемо тільки від душі побажати, щоб вони ...nіклувалися про гарлонійний розвиток майбутніх своїх вихованців, були справжніли носіяли просвітництва і служителяли тієї педагогіки, яка найбільше дбає про високі ідеали Істини, Добра і Краси» (курсив наш. - М. Д.) (Демков, 1894в: 227). Як бачимо з наведеного вище, образ учителя-дидакта у системі М. І. Демкова підпорядкований іпостасі вчителя-вихователя як високоморального взірця.

Постулати високої моральності є визначальними для M. I. Демкова, в ній він убачає стрижень усіх шкільних реформ, що постійно супроводжують школу як соціальний інститут. Ідеали Істини, Добра і Краси, вважає вчений, повинні бути незмінними для шкільного життя, бути серцевиною усіх реформістських процесів у школі. Він зазначає з цього приводу: "Досягти високого морального життя, наблизитися до ідеалів Істини, Добра й Краси було і буде завжди завданням кожної здорової педагогіки, яких би ре- 
форм вона не зазнала в майбутньому. Небагатьом це вдається. Але хто спробував солодкого, не захоче гіркого, і хто відчув високі радощі внутрішнього духовного життя, той не проміняє їх ні на що інше» (Демков, 1894в: 227).

Про те, наскільки значущою для М. І. Демкова як ученого була проблема гармонійного розвитку особистості, свідчить той факт, що саме її розгляд він кладе в основу своєї промови. Варто зазначити, що ще до виголошення цієї промови, до 1894 року, вчений презентує науковій і педагогічній громадськості власне бачення таких важливих проблем, як філософська і педагогічна підготовка вчителя, сімейне і моральне виховання особистості.

Ось як вишукано він розпочинає розгляд проблеми гармонійного розвитку: «Сьогодні я хотів би звернути вашу прихильну увагу на одне питання, яке в галузі педагогіки зайлає перше і видатне місие. Я лаю на увазі питання про гарлонійний розвиток, який заповідала нам ще велика Греція» (курсив наш. - М. Д.) (Демков, 1894а: 209).

Беручи філософські знання за основу власних психолого-педагогічних досліджень, М. І. Демков водночас залишається вірним своєму теоретико-методологічному шляху наукового пошуку. Вже будучи відомим ученим, він має право дати таку оцінку давньогрецьким ученням, що створили міцну філософію, заклали фундамент для майбутньої науки: «Ми і тепер не будуємо жодної науки без того, щоб не спертися на закладений ними фундамент; часто ми зобов' язані їм першим ярусом, іноді й цілим крилом наукового знання...» (Демков, 1894а: 209-210). Шанобливе ставлення до грецького народу, його здобутків, його багатющої спадщини - «великого народу, який звершив стільки прекрасного в історії, подарував нам і великі філософські системи, і блискучі наукові теорії, заклав міцний фундамент європейської філософії, науки, мистецтва й літератури» (Демков, 1894а: 209), є незмінним упродовж усього творчого шляху М. І. Демкова. 
Учений порушує проблему детермінації здобутків стародавніх греків - «який рушій сприяв таким чудовим проявам у духовній сфері?». Він визначає у взаємозв'язку такі внутрішні - особистісні - й зовнішні чинники: тверду волю, глибоку жадобу до знань і виховання. Зокрема, вчений зазначає: «Було таких рушіїв кілька: тверда воля, глибока жадоба знань і чудове виховання» (Демков, 1894а: 209). Зовнішній чинник - виховання «...мало в собі стільки особливостей, було таким повним і розмірним, що недарма дістало назву гармонійного. I результати його величезні» (Демков, 1894а: 209).

Які ж риси ідеалу грецького виховання відзначає М. І. Демков?

Це - «зовнішня та внутрішня краса і доброта»;

- «тілесна й духовна юність»;

- «здоров'я і радісний настрій»;

- «гармонійний розвиток усіх фізичних і психічних сил і нахилів»;

- «людина досконала як зовні, так і внутрішньо» (Демков, 1894a: 210).

Як бачимо, М. І. Демков розглядає ідеал виховання крізь призму органічного поєднання зовнішніх і внутрішніх чинників; через єдність фізичного й психічного розвитку. 3 одного боку, це зовнішня краса, тілесна юність, здоров'я, гармонійний розвиток усіх фізичних сил, «людина досконала зовні». 3 іншого - це внутрішня краса і доброта, духовна юність, емоційне благополуччя - радісний настрій, гармонійний розвиток усіх психічних сил і нахилів, тобто внутрішньо досконала людина. Звертає на себе увагу принцип репрезентації М. I. Демковим ідеалу грецького виховання. Це не просто перелік суто фізичних і особистісних чеснот, це - бачення їх як органічної констеляції зовнішніх і внутрішніх детермінант.

M. I. Демков змальовує вичерпну картину грецького шляху становлення особистості через систему його чинників: гімнастичного, музичного, поетичного виховання та 
математики. Але, на думку вченого, вони були лише підгрунтям у грецькому вихованні: «Однак найвищим, найчистішим й ідеальним завершенням усього виховання грека була філософія» (Демков, 1894a: 211). I якщо грецька філософія, досягнувши високого рівня розвитку, слугує й нині, а Сократ, Платон і Арістотель є «провідними світочами на важкому шляху філософського й наукового дослідження , , то ідеали Греції щодо гармонійного розвитку всіх сил і здібностей особистості упродовж тисячоліть пройшли тернистий шлях: від їх забуття до однобічних крайнощів, за яких домінантним був то розвиток розуму, то розвиток волі.

I ось в останньому десятилітті XIX ст. М. I. Демков закликає до повернення виховання до ідеалів гармонійного розвитку особистості: «Нині, коли знову повертаються до заповітів стародавньої Греції, коли шукають у неї уроків і повчань, настійною є необхідність висунути питання про гарлонійний розвиток» (курсив наш. - М. Д.) (Демков, 1894a: 211).

Перш ніж проаналізувати сутність шляхів і чинників гармонійного розвитку, вчений констатує, що культурноісторичний поступ вносить свої корективи до його абрису: «Звичайно, упродовж двох тисяч років змінились обставини, змінились і люди. З’ явилися нові запити й вимоги. Наш гарлонійний розвиток у подробииях буде не той, який давався у давній Елладі, однак він буде тил салил за приниипол» (курсив наш. - М.Д.) (Демков, 1894а: 211).

Прикметними є особливості аналізу М. І. Демковим проблеми гармонійного розвитку. Первинним у його архітектоніці, вважає вчений, має бути фізичний розвиток. У його основу М. І. Демков покладає принцип-правило «У здоровому тілі - здоровий дух», що посідав домінантне місце в системі гармонійного розвитку давніх греків і римлян.

Узявши за підгрунтя цей принцип, М. І. Демков застерігає сучасників від однобічності у підході до виховання, від поширеного на той час акцентування уваги на розумово- 
му розвитку. На противагу цьому він обстоює таку думку: «I сучасна педагогія не повинна обмежуватися одним лише розумовим розвитком, навіть більше, одним розвитком душевних здібностей, вона повинна звертати серйозну увагу на правильний фізичний розвиток» (Демков, 1894а: 211).

Учений розглядає фізичний розвиток у тісному взаємозв' язку з психічним. З одного боку, він показує негативний вплив фізичної слабкості, фізичних негараздів на тріаду «розум - серце - воля»: «Фізичні страждання паралізують розум, породжують поганий настрій духу й ослаблюють волю». 3 іншого - він зазначає всебічний вплив фізичного розвитку на психічний.

Ось такими є його настанови:

- «свіжість і міцність тілесна полегшують будь-яке розумове напруження, сприяють ясності уяви й мислення, вселяють людині самовпевненість і енергію» ;

- «здорове тіло якнайповніше сприяє прекрасному чудовому формуванню розуму, серця і волі, тоді як хворобливість є надто великою перешкодою» (Демков, 1894а: 211-212).

Найкращими засобами фізичного виховання М. I. Демков вважає ігри та гімнастику, які «підвищують енергію і тим самим викликають нову діяльність», які «дають належний простір і належне обмеження особистій волі». Як бачимо з наведеного вище, М. І. Демков розглядає вплив фізичного розвитку на цілий спектр рис та особливостей особистості й особистісного розвитку.

Наступна визначальна теза М. I. Демкова полягає в тому, що фізичний розвиток є підгрунтям духовного: «Без правильного фізичного виховання не може бути успішним і духовне» .

Учений дає чітку настанову майбутнім учителям, у якій ним відображена квінтесенція гармонійності розвитку: "...Наше виховання для того, щоб бути гарлонійнил, повинно полягати у суворо пропориійнолу форлуванні 
розулу, вихованні почуття $і$ волі» (курсив наш. - М. Д.) (Демков, 1894а: 212).

При цьому важливим є бачення того шляху, яким можна досягти гармонійного розвитку. Демков переконаний у тому, що «одним із головних знарядь для досягнення цього гарлонійного розвитку буде так зване виховне навчання» (курсив наш. - М.Д.) (Демков, 1894б: 217).

Варто зазначити, що сама по собі кожна з цих двох центральних ідей у суспільно-освітньому соціумі була самодостатньою і доволі відокремленою у своїй історико-культурній ґенезі. Проте визначальною рисою М. І. Демкова як ученого є його новаторський талант, що сприяв репрезентації цих ідей науково-педагогічній громадськості крізь призму синтезованого їх бачення у тогочасному освітньому просторі. Це, з одного боку, ідея гармонійного виховання, гармонійного розвитку дитячої особистості, а $з$ іншого виховне навчання як один із головних чинників такого розвитку - в їх нерозривній органічній єдності.

M. I. Демков вважає своїм обов'язком принципово окреслити ще дві проблеми. Одна - це статус учителя в педагогічному процесі, на який він звертає увагу випускників, удостоєних звання міських учителів: «Сучасний учитель насамперед педагог, він повинен розум виховувати і виховуючи навчати» (Демков, 18946: 217). I друга - це наголошення на органічній єдності навчання і виховання: «Одне лише навчання без виховання вважається таким, що не досягає мети» (Демков, 1894б: 217). Аналізуючи проблему розуму як засадничої складової гармонійного розвитку особистості, Демков акцентує увагу майбутніх педагогів на тих стрижневих моментах, що повинні перебувати в полі їх зору. У стислій формі вчений вичерпно розкриває проблему розумового розвитку в різних векторах - i через системність і цілісність засвоєних школярем знань, і через продуктивне оволодіння ним поняттєвою формою мислення: «Розвиваючи розум, забезпечуючи його різноманітними і численними знаннями, сучасний педагог дбає, 
щоб ці знання не були розкиданими і безсистемними, він насамперед за правилами великих філософів намагається сформувати у своїх учнів ясні й точні поняття» (Демков, 1894б: 217).

Важливим є й те, що М. І. Демков, акцентуючи увагу майбутнього вчителя на розумовому розвитку, побічно застерігає його від можливих помилок, яких може припуститися молодий учитель у своїй роботі. Учений антиципіює їх можливу появу й у зв’язку з цим наголошує: «...щоб ці знання не були розкиданими й безсистемними» і показує шлях, як уникнути цього.

M. I. Демков у виголошеній промові, яка нібито за жанром - звернення до майбутніх учителів - повинна містити певний відтінок повчальності, моралізування, повністю відходить від такого стилю викладу. Вчений у сконцентрованому вигляді доносить до майбутнього вчителя своє бачення того, що має робити педагог для задоволення вимог сучасності. У такій формі він екстраполює образ ідеального вчителя на площину професійної самосвідомості молодого педагога.

Привертають увагу стильові характеристики М. I. Демковим діяльності педагога у системі взаємодії «учитель - учень», а також делікатність, яку він делегує молодому вчителеві в його роботі, бережливість тієї форми, у якій учитель повинен розвивати розум і передавати знання дитині, як-от: «сучасний педагог піклується, щоб ці знання...», «прагне забезпечити своїх учнів...», «педагог намагатиметься...» - його настанови були спрямовані на розвиток фасилітативної взаємодії у навчальному процесі.

Аналізуючи проблему гармонійного розвитку, вчений виступає як вдумливий дитячий і педагогічний психолог. Його концептуальний підхід до проблеми гармонійного розвитку - це тонке поєднання знання дитячої психології зі знанням здійснення виховного впливу в процесі включення дитини до шкільного навчання та шкільного соціуму . 
Як дитячий психолог він дає широку палітру онтогенетичного розвитку. «Педагог повинен пам'ятати, - наголошує вчений, - що роки дитинства - це найкращий час у житті людини для набуття різноманітних відчуттів і уявлень, узагалі знань про навколишню природу; ...юнацький же вік - це найкращий період для вироблення ідеалів і принципів, якими повинна керуватися людина в житті особистому й суспільному» (Демков, 1894б: 217).

Як педагогічний психолог він органічно аналізує сутнісні навчально-виховні механізми не лише засвоєння знань дитиною, а й її особистісного розвитку в процесі навчальної діяльності.

M. I. Демков привертає увагу майбутнього вчителя до таких важливих проблем, як:

- розвиток спостережливості у дітей;

- пробудження у дитини уваги до навчального матеріалу;

- розвиток у дитини інтересу до навчання;

- привчання дитини до розумової праці;

- роль і зміст наочності, а також своєрідність їі використання у навчальному процесі залежно від вікових особливостей дітей.

Учений обстоює постулат саме внутрішньої детермінації навчальної діяльності, причому ідея внутрішньої детермінованості пронизує процес навчання у двох взаємопересічних площинах.

Перша - це внутрішня детермінованість, що лежить у самій структурі засвоюваних школярами знань у процесі навчання і яка є стрижнем цих знань. «Учитель, - зазначає М. І. Демков, - повинен прагнути до того, щоб не одні лише зовнішні факти і явища привертали увагу учнів, а й ті найвищі духовні чинники, які становлять душу предмета і яких прийнято називати «центральними головними ідеями», які групують навколо себе другорядні поняття, об’єднують і узагальнюють їх» (Демков, 1894б: 218). 
Друга площина - це «дух навчання», що внутрішньо детермінує навчання як мегасистему шкільного соціуму. Ось як розгортає вчений цю проблему перед випускниками вчительського інституту: «На нашу думку, навчання буде залежати від того, наскільки вчитель буде пройнятий великим Платоновим принципом об'єднання та узагальнення; наскільки у його навчанні буде проглядати щира, беззастережна відданість науці; любов до дітей і взятої на себе важкої педагогічної справи» (Демков, 1894б: 218).

Для підходу М. І. Демкова до особистісного розвитку характерні такі три визначальні риси, від яких залежить дух навчання у шкільному просторі.

По-перше, це відданість педагога науці - щира, беззастережна, яка має пронизувати, за М. I. Демковим, процес навчання. Ця його настанова є актуальною навіть для XXI століття. Тут варто враховувати ще й той факт, що вчений включав цю складову до свого бачення духу навчання не університетських випускників, а випускників нижчих за кваліфікаційним рівнем закладів, що ними були вчительські інститути наприкінці XIX ст.

По-друге, любов учителя до дітей, що є віддзеркаленням іманентно властивої вітчизняній науці традиції - гуманістичної.

По-третє, це, за сучасною термінологією, наявність у вчителя інтернального локусу контролю. Але М. І. Демков подає цю рису не як сухий імператив обов'язку, а як неодмінну складову педагогічної любові - любові до «взятої на себе важкої педагогічної справи» .

Слід зазначити, що чітка структурованість розгляду проблеми характерна для всього наукового пошуку M. I. Демкова. Так, аналізуючи проблему гармонійного розвитку, вчений репрезентує її бачення шляхом багатовекторного розгортання крізь:

- розкриття гармонійного розвитку в історико-філософському ракурсі; 
- окреслення основного підгрунтя - фізичного розвитку;

- чітке визначення категорії «гармонійний розвиток»;

- засадничу його детермінацію - «головне знаряддя для досягнення цього гармонійного розвитку»;

- абрис його структурних складових: «у чому саме може полягати гармонійний розвиток розуму, почуття, волі» .

Необхідно зазначити, що середина останнього десятиліття XIX ст. у вітчизняній психолого-педагогічній думці ознаменувалася продуктивними науковими розробками, що не втратили актуальності й донині. Одним зі здобутків цього періоду є концепція гармонійного розвитку, створена видатним вітчизняним ученим М. I. Демковим.

Перейдемо до розгляду проблеми «духу навчання» у контексті творчої спадщини М. I. Демкова. Принципово новою для тогочасного наукового знання була розробка M. I. Демковим проблеми «духу навчання» - як вихідного принципу діяльності вчителя: «Якщо діяльність учителя вимірюється всією сукупністю уроків, то важливий той первень, який ними керує, важливий той принцип, яким керується вчитель, важливий той «дух», який у них присутній. Із усього сказаного раніше очевидно, що всього цього не можна шукати в зовнішніх форлах» (курсив наш. - М. Д.) (Демков, 1893: 153).

Оригінальність розробки вченим однієї з найважливіших проблем - «духу навчання» - визначається розглядом її в контексті особистісного підходу. Він іде своїм, самобутнім шляхом у розв'язанні цієї основоположної проблеми для життєдіяльності школи, коректно обстоюючи власну думку. Зауважимо, що втрачена у XX ст. з плином часу проблема «духу навчання» у XIX ст. мала різні витлумачення. Наприклад, відомий вітчизняний педагог М. Олесницький (його «Курс педагогіки» у двох частинах, виданий у 80-х pp. XIX ст. у Києві), який користувався заслуженою повагою і популярністю, означував свій підхід до пробле- 
ми «духу навчання», віддаючи перевагу зовнішній його стороні - тону, манері, техніці навчання. «З внутрішнього боку, - зазначав він, - навчання виявляється у настрої, 3 яким учитель починає свою справу і веде їі. А із зовнішнього боку воно виявляється у голосі й рухах тіла. Виявлене в голосі має назву - тон навчання, а виявлене в рухах - манера навчання; а поєднання того й того назвемо технікою навчання. I педагоги одностайно визнають, що кожний учитель має опанувати якщо не свій особливий метод, то свою особливу дидактичну техніку. ...УЧитель повинен звертати увагу і на свій зовнішній вигляд, уникаючи чи то в одягу, чи у рухах, чи в будь-чому іншому всього того, через що він може втрачати свою гідність в очах учнів, або розсіювати їх (Олесницький, 1887: 121).

Надаючи належного значення і голосу, і тону, і манерам учителя у викладанні, Демков висловлює незгоду 3 усталеним на той час поглядом про місце їх розкриття у контексті проблеми про «дух навчання»: «Визначаючи зі свого боку, що і голос, і тон, і рухи тіла (манери) багато важать у справі викладання , але, заперечує він Олесницькому, «про них треба вести мову в іншому місці, а не в розділі «Про дух навчання» (Демков, 1893: 154). Учений обстоює протилежну позицію, що відзначається принциповою новизною. Він дає визначення «духу навчання», вважаючи його лише внутрішнім, духовним. Особистості вчителя відводиться провідна роль у створенні «духу навчання», це, за Демковим, визначальний чинник навчання, за яким ідуть такі чинники, як «дух усього навчального закладу» та вимоги певного часу.

Зважаючи на те, що це перше більш як за століття відтворення концептуального підходу М. І. Демкова, з метою збереження авторської неповторності, наведемо визначення «духу навчання» в авторській редакції. «Духу належить тільки внутрішнє, духовне. Тому дух навчання складається лише з внутрішніх, духовних факторів. На нашу думку, дух навчання залежатиме від того, наскільки вчитель буде 
проникнутий великим Платонівським принципом узагальнення та об'єднання, наскільки в його навчанні проглядатиме щира, беззастережна відданість науці, любов до дітей і взятої на себе важкої педагогічної справи. Якщо вчитель усе виконуватиме формально, по шаблону, звичайним порядком, то й духу ніякого не буде, буде тільки одна омертвіла форма. Тому дух навчання передусім і найбільше залежить від особистості вчителя, потім від духу всього навчального закладу i, нарешті, деякою мірою від вимог даного часу» (Демков, 1893: 154).

Принциповою новизною для концептуального підходу вченого є розгляд М. I. Демковим проблеми детермінації навчання. Непересічною заслугою розробки ним проблеми «духу навчання» став його аналіз органічної єдності особистісної та суспільної детермінації.

Учений віддає належне соціальним чинникам, розглядаючи вплив на «дух навчання» мегасистеми - суспільства як стрижневої соціальної детермінанти. Надзвичайно сучасною й актуальною є думка, висловлена вітчизняним ученим понад 110 років тому. «Якщо в суспільстві й у вищих сферах учитель дістає активну підтримку своїх прагнень до високих ідеалів істини, добра й краси, якщо його прагнення й запити не є голосом волаючого в пустелі, то згодом це не забариться позначитися і на всьому викладанні, на дусі навчання. Учитель відчуває, що він не один, що поруч із ним і понад ним шукають такої самої правди, і це надає йому сили й енергії, оживляє його дух, а отже, живить і все навчання» (Демков, 1893: 155).

Соціальна детермінація знаходить вираження у концептуальному підході Демкова до "духу навчання» також у наступній детермінанті - макросистемі шкільного соціуму. «Якщо в своєму середовищі, серед товаришів-учителів і батьків, учитель має довіру, підтримку, пораду і настановлення, якщо вся корпорація з директором на чолі, натхненні щирою любов’ю до педагогічної справи, якщо ця любов виявляється в усьому житті школи...то багато 
шансів, що у навчанні вчителя так чи інакше відображатиметься дух школи і саме викладання стане живим, цікавим» (Демков, 1893: 155).

Особистість учителя, як уже зазначалося вище, є, за Демковим, стрижневим чинником «духу навчання». Це він наголошує неодноразово: "...передусім і найбільше «дух навчання» залежить від особистості вчителя. Добре, звичайно, якщо і суспільство, і школа, і дух часу сприяють діяльності вчителя; але й за найнесприятливіших обставин учитель - справжній педагог, і тому справжній носій освіти може впливати розумово й морально на учнів і високо тримати прапор тієї педагогіки, на якому яскравими літерами написано: «Істина, Добро і Краса» (Демков, 1893: 155).

Розгортаючи проблему особистісної детермінації, M. I. Демков постійно звертається до особистості вчителя, обстоюючи в органічній єдності дві засади: високоморальність і високоосвіченість. Він обстоює тезу, що дух навчання є лише тоді, коли вчитель вносить «морально-виховний елемент у своє навчання». «Навчання, - наголошує вчений, - є тільки тоді морально-виховним, коли проникнуте щирою, гарячою, непідробною любов'ю до учнів, справжньою і нелицемірною любов'ю до батьківщини (справжній патріотизм), глибоким розумінням національних завдань та інтересів. Цим обгрунтовується необхідність, щоб педагог був людиною високоморальною і високоосвіченою» (Демков, 1893: 155-156).

Учений, обстоюючи тезу, що «особистість високоморального і високоосвіченого педагога має особливу цінність», акцентує: "дух таких особистостей живить школу, що без них вона ніщо» (Демков, 1893: 156).

Непересічним за значущістю є здійснений М. I. Демковим абрис еталонного образу вчителя: «...педагогу, як носію найвищих ідеалів, як провіднику наукових, естетичних i моральних ідей, потрібно бути людиною високоосвіченою. Лише за умови широкої і глибокої філософської й наукової освіти, педагог матиме можливість бути носієм освіти 
і вносити в школу, а через неї і в життя, світло і «дух живий». Ось чому такою важливою і цінною є особистість високоморального та високоосвіченого педагога, який часто задає тон усій школі. І чудово, що навіть 1-2 такі людини можуть справити значний вплив на школу. Тут значення більшості применшується, малоактивна більшість стушовується, бо не безособова більшість управляє долею школи, а ті діяльні, світлі особистості, з глибокою філософською підготовкою і високими моральними принципами керують ïï життям. Як же після цього не сказати, що дух таких особистостей живить школу, що без них вона ніщо» (Демков, 1893: 156).

Квінтесенція підходу М. І. Демкова до проблеми «духу навчання» міститься у таких смислових спектрах:

- «духу належить тільки внутрішнє, духовне»;

- «дух навчання складається тільки з внутрішніх, духовних чинників»;

- «дух навчання насамперед і найбільше залежить від особистості вчителя» (Демков, 1893).

Проблема «духу навчання» у шкільному середовищі сьогодні одна з найактуальніших проблем не лише соціальної та педагогічної психології, а й педагогічної практики.

Це проблеми:

- екології психічного здоров'я дитини в перевантаженому інформаційно шкільному просторі;

- особистісної «ціни» навчальних досягнень школяра;

- комфортності включення дитини у шкільний соціум;

- емоційного благополуччя дитини у процесі навчальної діяльності на «сходинках» навчальних досягнень;

- комфортності особистісного статусу школяра у процесі навчання.

Сучасне осмислення окреслених вище проблем вимагає проведення масштабних соціально-психологічних досліджень у таких системах, як «навчання - учень», «учень шкільне середовище» . 


\section{Висновки}

Наприкінці XIX ст. видатним вітчизняним ученим, педагогом M. I. Демковим розроблено цілий спектр проблем дитячої та педагогічної психології, які залишаються в забутті й донині. У статті здійснено теоретико-методологічний аналіз психологічної системи М. I. Демкова у контексті концептуальних парадигм гармонійного розвитку особистості та «духу навчання» в освітньому просторі. M. I. Демковим зроблено неоціненний внесок у побудову теоретико-методологічного фундаменту освітнього процесу. Він першим в українській психології кінця XIX ст. порушив проблему гармонійного розвитку, розкрив його концептуальну сутність і архітектоніку. Квінтесенцію гармонійного розвитку вчений означує як «суворо пропорційне формування розуму, виховання почуття і волі». Проблему гармонійного розвитку М. I. Демков репрезентує через багатовекторне розгортання спектрів: розкриття гармонійного розвитку в історико-філософському ракурсі; окреслення основного підгрунтя - фізичного розвитку; визначення концепту «гармонійний розвиток», засадничої його детермінації - «головне знаряддя для досягнення цього гармонійного розвитку»; абрис його структурних складових: «у чому саме може полягати гармонійний розвиток розуму, почуття, волі». Непересічною є здійснена М. I. Демковим у царині дитячої психології об'ємна палітра онтогенетичного розвитку; в царині педагогічної психології - сутнісна характеристика як засвоєння знань дитиною, так і становлення особистості у процесі учіння. Актуалізована ним проблема попередження деструкції гармонійного розвитку й однобічності особистісного розвитку дає змогу оптимізувати екологічність особистісного становлення у шкільному середовищі. 3'ясовані вченим стильові характеристики діяльності педагога у системі взаємодії «вчитель - учень» спрямовані на розвиток фасилітативної взаємодії в освітньому просторі. Прикметно, що М. І. Демков обстоює постулат внутрішньої детермінації навчальної діяльності. 
Концептуальне бачення М. I. Демковим проблеми «духу навчання» як органічної єдності особистісної та суспільної детермінації дає можливість з’ясувати вплив мегасистеми - суспільної, а також макросистеми - шкільного соціуму на ефективність її перебігу. Принципово важливим $є$ розкриття М. І. Демковим домінантності стрижневого чинника «духу навчання»- особистості вчителя як констеляції високоморальності та високоосвіченості, а також окреслений ним абрис еталонного образу вчителя. Екстраполяція проблеми «духу навчання» у сучасний освітній простір сприятиме екологічності систем «учень - учитель» та «учень - шкільне середовище» .

Перспектива подальшого дослідження передбачає теоретико-методологічний аналіз концептуальних парадигм, що складають сутність психологічної системи М. I. Демкова.

\section{Література}

Бєлкіна Н. І. Освітня діяльність і педагогічні погляди М. І. Демкова (1859-1939): автореф. дис. ... канд. пед. наук: спец. 13.00.01 «Теорія та історія педагогіки». Ніжин, 1998. 22 с.

Демков М. И. (а). О гармоническом развитии. Педагогический еженедельник. Издание журнала «Гимназия». 1894. № 27. С. 209-212.

Демков М. И. (б). О гармоническом развитии. Педагогический еженедельник. Издание журнала «Гимназия». 1894. № 28. С. 217-220.

Демков М. И. (в). О гармоническом развитии. Педагогический еженедельник. Издание журнала «Гимназия». 1894. № 29. С. 225-227.

Демков М. И. О самостоятельных занятиях учащихся (к вопросу о воспитании воли). Гимназия. 1889. № 11. С. 600-613.

Демков М. И. О ходе урока и духе обучения. Педагогический сборник. 1893. № 8. С. 141-156.

Дригус М. Т. Проблеми виховання волі у творчій спадщині М. І. Демкова. Філософія, соціологія, психологія: Збірник наукових пращь. ІваноФранківськ : ВДВ ЦІТ, 2006. Вип. 11-12. С. 92-97.

Дригус М. Т. Психолого-педагогічна система виховання у творчій спадщині М. І. Демкова. Проблеми загальної та педагогічної психології: Зб. наукових праць Інституту психологї імені Г. С. Костюка АПН України / За ред. С. Д. Максименка. Київ, 2004. T. VI. Вип. 4. С. 106-111. 
Максименко С. Д. Генеза здійснення особистості. Київ : Видавництво $\mathrm{TOB} « \mathrm{KMM},, 2006.240$ c.

Олесницкий М. Курс педагогики. Киев, 1887. Вып. 2. 427 с.

Педагогическая энциклопедия. Москва, 1929. Т. 1. 1158 с.

Психологічна спадщина К. Д. Ушинського / За ред. С. Г. Костюка. Київ, 1963. $234 \mathrm{c}$.

Рибалка В. В. Теорії особистості у вітчизняній філософії, психології і педагогіці: посібник. Житомир : Вид-во ЖДДУ ім. І. Франка, 2015. 872 c.

Рождественський Ю. Т. Психологія в Україні XVII - початку XIX ст. (спроба реконструкції та систематизації академічної спадщини). Умань : ПП Жовтий, 2012. 252 с.

Самоплавська Т. О. Демков Михайло Іванович. Украӥнська педагогіка в персоналіях: у 2 кн. / За ред. О. В. Сухомлинської. Кн. 2. ХХ століття. Київ : Либідь, 2005. С. 129-135.

Становлення психологічної думки в Україні: провідні ідеї та історія розвитку: колективна монографія / В. В. Турбан, Л. З. Сердюк, Ю. Т. Рождественський [та ін.]; за ред. В. В. Турбан. Кіровоград : Імекс-ЛТД, 2014. 306 с.

Українська педагогіка в персоналіях: у 2 кн. / За ред. О. В. Сухомлинської. Кн. 1. IX-XIX століття. Київ : Либідь, 2005. 624 с.

Українська педагогіка в персоналіях: у 2 кн. / За ред. О. В. Сухомлинської. Кн. 2. ХХ століття. Київ : Либідь, 2005. 552 с.

Філософська думка в Україні: бібліографічний словник / Авт. кол.: В. С. Горський, М. Л. Ткачук, В. М. Нічик та ін. Київ : Вид-во «Пульсари», 2002. 244 с.

Saugstad, P. (2001). Psykologins Historia. En introduktion i modern psykologi. Stockholm : Natur \& Kultur.

Saugstad, P. (2009). Psykologiens historie (revidert utg.). Oslo : Gyldendal Akademisk.

Saugstad, P. (2018). A History of Modern Psychology. Cambridge University Press. Retrieved from htpps://doi:10.1017/9781316272442.

\section{References}

Bielkina, N. I. (1998). Osvitnia diialnist i pedahohichni pohliady M. I. Demkova (1859-1939) [Educational activity and pedagogical views of M. Demkov (1859-1939)]. Extended abstract of candidate's thesis. Nizhyn [in Ukrainian].

Demkov, M. I. (1894a). O garmonicheskom razvitii [On harmonious development]. Pedagogicheskij ezhenedel'nik. Izdanie zhurnala "Gimnazija»-Publication of the journal «Gimnaziia», 27, 209-212 [in Russian]. 
Demkov, M. I. (1894b). O garmonicheskom razvitii [On harmonious development]. Pedagogicheskij ezhenedel'nik. Izdanie zhurnala «Gimnazija»-Publication of the journal «Gimnaziia», 28, 217-220 [in Russian].

Demkov, M. I. (1894c). O garmonicheskom razvitii [On harmonious development]. Pedagogicheskij ezhenedel'nik. Izdanie zhurnala "Gimnazija» - Publication of the journal "Gimnaziia», 29, 225-227 [in Russian].

Demkov, M. I. (1889). O samostojatel'nykh zanjatijah uchashchihsja (k voprosu o vospitanii voli) [On independent work of pupils (to the question of will development)]. Gimnazija - Gimnaziia, 11, 600-613 [in Russian].

Demkov, M. I. (1893). O hode uroka i duhe obuchenija [On the class-work course and the spirit of learning]. Pedagogicheskij sbornik - Pedagogical collection, 8, 141-156 [in Russian].

Dryhus, M. T. (2006). Problemy vykhovannia voli u tvorchii spadshchyni M. I. Demkova [The issue of will development in the creative heritage of M. I. Demkov]. Filosofiia, sotsiolohiia, psykholohiia: Zbirnyk naukovykh prats - Philosophy, sociology, psychology : Collection of scientific works, 11-12, 92-97. Ivano-Frankivsk : VDV TsIT [in Ukrainian].

Dryhus, M. T. (2004). Psykholoho-pedahohichna systema vykhovannia u tvorchii spadshchyni M. I. Demkova [The psychological-pedagogical system of education in the creative heritage of M. I. Demkov]. S. D. Maksymenko (Eds.). Problemy zahalnoi ta pedahohichnoi psykholohii - Problems of general and pedagogical psychology: Collection of research papers of G. S. Kostiuk Institute of Psychology at the National Academy Of Pedagogical Sciences of Ukraine, VI, Issue 4, 106111. Kyiv [in Ukrainian].

Maksymenko, S. D. (2006). Heneza zdiisnennia osobystosti [Genesis of personal realization ]. Kyiv : Vydavnytstvo TOV «KMM» [in Ukrainian].

Olesnickij, M. (1887). Kurs pedagogiki [Lectures on pedagogy]. (Issue 2). Kiev [in Russian].

Pedagogicheskaja jentsiklopedija [Pedagogical Encyclopaedia]. (1929). (Vol. 1). Moskva [in Russian].

Kostiuk, S. H. (Eds.) (1963). Psykholohichna spadshchyna K. D. Ushynskoho [The psychological heritage of K. D. Ushynskyi]. Kyiv : Radianska shkola [in Ukrainian].

Rybalka, V. V. (2015). Teorii osobystosti u vitchyznianii filosofii, psykholohii i pedahohitsi [Theories of a personality in the national philosophy, psychology and pedagogy]. Zhytomyr : Vyd-vo ZhDU im. I. Franka [in Ukrainian].

Rozhdestvenskyi, Yu. T. (2012). Psykholohiia v Ukraini XVII - pochatku XIX st. (sproba rekonstruktsii ta systematyzatsii akademichnoi spad- 
shchyny) [Psychology in Ukraine in the XVII - early XIX century (an attempt to reconstruction and systematization of the academic heritage)]. Uman : PP Zhovtyi [in Ukrainian].

Samoplavska, T. O. (2005). Demkov Mykhailo Ivanovych [Demkov Mykhailo Ivanovych]. O. V. Sukhomlynska (Ed.). Ukrainska pedahohika $v$ personaliiakh - Ukrainian pedagogy in personalities (Vol. 2: XX century, pp. 129-135). Kyiv : Lybid [in Ukrainian].

Turban, V. V., Serdiuk, L. Z., Rozhdestvenskyi, Yu. T., Lettsev, V. M., Bilokon, I. V., Melnyk, O. A. et al. (2014). Stanovlennia psykholohichnoi dumky $v$ Ukraini: providni idei ta istoriia rozvytku [Formation of psychological thought in Ukraine: leading ideas and history of development]. Kirovohrad : Imeks-LTD [in Ukrainian].

Sukhomlynska, O. V. (Ed.) (2005a). Ukrainska pedahohika v personaliiakh [Ukrainian pedagogy in personalities] (Vol. 1: IX-XIX centuries). Kyiv : Lybid [in Ukrainian].

Sukhomlynska, O. V. (Ed.) (2005b). Ukrainska pedahohika v personaliiakh [Ukrainian pedagogy in personalities] (Vol. 2: XX century). Kyiv : Lybid [in Ukrainian]

Horskyi, V.S., Tkachuk, M. L., Nichyk, V. M., Bilodid, V. D., Stratii, Ya. M., Lysyi, I. Ya. et al. (2002). Filosofska dumka v Ukraini [Philosophical thought in Ukraine]. Kyiv : Vyd-vo "Pulsary» [in Ukrainian].

Saugstad, P. (2001). Psykologins Historia. En introduktion i modern psykologi. Stockholm : Natur \& Kultur.

Saugstad, P. (2009). Psykologiens historie (revidert utg.). Oslo : Gyldendal Akademisk.

Saugstad, P. (2018). A History of Modern Psychology. Cambridge University Press. Retrieved from htpps://doi:10.1017/9781316272442.

\section{Дригус Марія. Концептуальні парадигми психологічної системи М. І. Демкова}

\section{АНОТАЦІЯ}

У статmі представлено результати дослідження концептуальних парадигм психологічної системи М. І. Демкова. Здійснено теоретикометодологічний аналіз психологічної системи М. І. Демкова у контексті концептуальних парадигм гармонійного розвитку особистості ma "духу навчання» в освітньому просторі. Репрезентовано реконструкцію концепції гармонійного розвитку особистості М. І. Демкова. Розкрито концептуальне бачення ученим сучасності гармонійного розвитку, його архітектоніки. Висвітлено квінтесенцію гармонійного розвитку як «суворо пропорційного фрормування розуму, виховання почуття $i$ волі». Акцентовано на баченні М. І. Демковим виховуючого навчання як 
чинника гармонійного розвитку дитячої особистості. Констатовано, що М. І. Демков у царині дитячої психології дав об'ємну палітру онтогенетичного розвитку; в царині педагогічної психології він органічно розкрив сутнісні характеристики не лише засвоєння знань дитиною, а й становлення особистості у процесі учіння. Актуалізовано проблему попередження деструкції гармонійного розвитку й однобічності особистісного розвитку. З'ясовано стильові характеристики діяльності педагога у системі взаємодії "вчитель - учень», спрямовані на розвиток фрасилітативної взаємодії. Акцентовано на тому, шо М. І. Демков обстоював постулат внутрішньої детермінації навчальної діяльності.

Висвітлено концептуальне бачення М. І. Демковим проблеми «духу навчання» як органічної єдності особистісної та суспільної детермінації. 3'ясовано вплив мегасистеми - суспільної, а також макросистеми шкільного соціуму. Розкрито домінантність, за М. І. Демковим, стрижневого чинника "духу навчання» - особистості вчителя як констеляції високоморальності та високоосвіченості. Зафіксовано введення М. І. Демковим концептів - "морально-виховний елемент», "морально-виховне» у характеристику навчальної діяльності. Розкрито окреслений М. І. Демковим абрис еталонного образу вчителя. Виокремлено смислові й сенсотвірні спектри квінтесенції підходу М. І. Демкова у парадигмі «дух навчання». Здійснено екстраполяцію проблеми «духу навчання» у сучасний освітній простір.

Ключові слова: виховання, гармонійний розвиток, детермінація, особистість, психологічна система, чинники.

\section{Дригус Мария. Концептуальные парадигмы психологической системы М. И. Демкова}

\section{АННОТАЦИЯ}

В статье представлены результаты исследования концептуальных парадигм психологической системы М. И. Демкова. Осуществлен теоретико-методологический анализ психологической системы М. И. Демкова в контексте концептуальных парадигм гармонического развития личности и «духа обучения» в образовательном пространстве. Репрезентирована реконструкция концепции гармонического развития личности, созданной М. И. Демковым. Раскрыто концептуальное видение ученым сущности гармонического развития, его архитектоники, освещена квинтэссенция гармонического развития как «строго пропорционального формирования разума, воспитания чувства и воли». Акцен- 
тировано видение М. И. Демковым воспитывающего обучения как фактора гармонического развития детской личности. Констатировано, что М. И. Демков в сфере детской психологии дал объемную палитру онтогенетического развития; в срере педагогической психологии он органически раскрыл содержательные характеристики не только усвоения знаний ребенком, но и его личностное становление в процессе учения. Актуализирована проблема упреждения деструкции гармонического развития и односторонности личностного развития. Установлены стилевые характеристики деятельности педагога в системе взаимодействия "учитель - ученик» с иелью развития фасилитативного взаимодействия. Акцентировано на том, что для М. И. Демкова доминантной является внутренняя детерминация учебной деятельности.

Раскрыто концептуальное видение М. И. Демковым проблемы "духа обучения» как органического единства личностной и общественной детерминации. Установлено влияние мегасистемы - общественной, а также макросистемы - школьного социума. По М. И. Демкову, стержневой фактор "духа обучения» -личность учителя как констелляция высокоморальности и высокообразованности. Зафиксировано введение М. И. Демковым концептов - «морально-воспитательный элемент», "морально-воспитательное» в характеристику учебной деятельности. Раскрыт очерченный М. И. Демковым абрис эталонного образа учителя. Выделены содержательные и смыслообразующие спектры квинтэссенции подхода М. И. Демкова в парадигме «дух обучения». Осуществлена экстраполяция проблемы "духа обучения» в современное образовательное пространство.

Ключевые слова: воспитание, гармоническое развитие, детерминация, личность, психологическая система, факторы. 